AUTOR

\section{Emerson Urizzi} Cervi*

ecervi7@gmail.com

* Doutor em Ciência Política; professor adjunto da Universidade Federal do Paraná

\section{Effective number of candidates and} regional wealth in campaign finance analyses: A methodological proposal for comparing the effects of the monetization of election campaigns in Brazil

Número de candidatos y desarrollo regional en análisis de financiación de campañas: una propuesta metodológica para comparar los efectos de la monetización de las campañas electorales en Brasil

Número efetivo de candidatos e desenvolvimento regional em análises de financiamento de campanhas: uma proposta metodológica para comparar os efeitos da monetarização das campanhas eleitorais no Brasil

\begin{abstract}
This paper is an empirical study to measure the impact of financial resources on election campaigns. As Brazil is a large country with economically, politically and socially heterogeneous electoral districts, it is difficult to make direct comparisons regarding the impact of campaign financing on national elections. The study sets out by assuming that campaign resources have different effects depending on the levels of political competitiveness and local wealth. The aim of the study is to propose a model that will allow different campaign situations to be put on the same level in order to conduct a comparative evaluation of the impacts that financial resources make on elections. For this purpose, the data for the 2010 elections for Federal Deputy will be used.
\end{abstract}

\section{RESUMEN}

El trabajo presenta estudio empírico sobre el efecto de los recursos financieros en los resultados electorales. En Brasil, debido a que es un país de grandes extensiones y heterogeneidad económica, política y social en los distritos electorales, las comparaciones directas son difíciles. Se parte del princpio de que los recursos de campaña tienen pesos diferentes en función de los niveles de la competición politica y de la riqueza regional. Tenemos la intención de proponer un modelo que permite igualar las diferentes condiciones de campaña para evaluar los impactos de los recursos financieros en las disputas. Para ello, hemos utilizado los datos sobre las elecciones de 2010 para diputado federal.

\section{RESUMO}

O artigo apresenta um estudo empírico sobre dos recursos financeiros em resultados eleitorais em democracia de massa. No caso do Brasil, por se tratar de um País de grandes extensões e heterogeneidade econômica, política e social nos distritos eleitorais, as comparações diretas são difíceis. Parte-se do princípio que recursos de campanha têm peso distinto em função dos níveis de concorrência política e da riqueza regional. Pretende-se propor um modelo que permita a equalizar distintas condições de campanha para avaliar os impactos dos recursos financeiros nas disputas. Para tanto, serão usados dados referentes às eleições de 2010 para Deputado Federal.. 


\section{Introduction}

KEYWORDS

Elections;

Studies of election results are among the most explored fields of political science when it comes to interpreting the complex elements of representative democracy. As has already been pointed out by Taagepera and Shugart (1989), these studies look at well defined and measureable numbers of votes, seats and candidates in order to arrive at more complex notions of the system as a whole. More recently, the measurable values of campaign finance resources have been added to the number of votes ${ }^{1}$. Figure 1 below shows the relationship between funds raised individually and the votes obtained by over four thousand candidates for federal deputy in Brazil during the 2010 elections. The coefficient of determination $\left(r^{2}\right)$ of 0.700 shows a strong relationship between money and votes. The more resources available, the greater the possibility of winning individual votes. This does not mean that money ensures victory, as there are socio-political factors other than economic ones that can account for how an election is won.

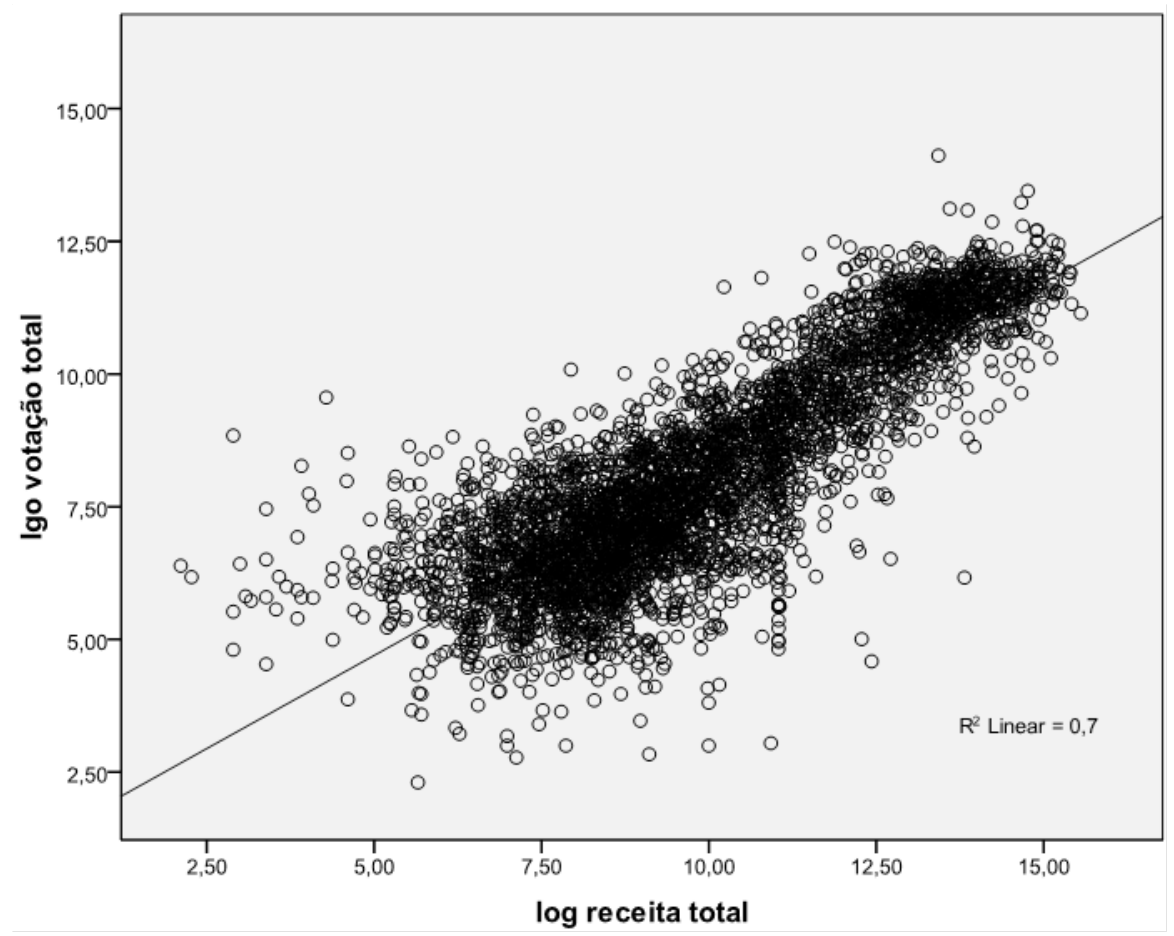

Figure 1 - Relationship between money raised (R\$) and individual votes obtained for federal deputy in the 2010 elections in Brazil ${ }^{2}$

Following the hints of a strong relationship between money and votes, Figure 2 below shows the same variable relationships. However, the colors distinguish the candidates of each of the Brazilian meso-regions. It shows that, even when the 27 electoral districts are viewed as five meso-regions, differences remain in the relationship between campaign donations and individual votes. For the northern region of the country, the $r^{2}$ is 0.661 ; for the north-east, the $r^{2}$ is 0.732 ; in the mid-west, the $r^{2}$ is 0.642 ; in the south-east, the $r^{2}$ is 0.713 , and in the south, the $r^{2}$ is 0.747 . The coefficients show that the degree of explanation of the region among the variables varies from one group to another. It is because of these differences that we will use two variables, one political and one economic, to compose an index for minimizing the regional effects of the impact of monetary resources on election campaigns and therefore improve the conditions for comparing them. federal deputy;

Brazil; campaign financing; electoral competitiveness.

PALABRAS CLAVE

Elecciones:

diputado federal;

Brasil; financiación electoral; competitividad

PALAVRAS-CHAVE

Eleições; deputado federal; Brasil; financiamento; competitividad

Recibido: 15.12.2014

Aceptado: 02.02.2015 


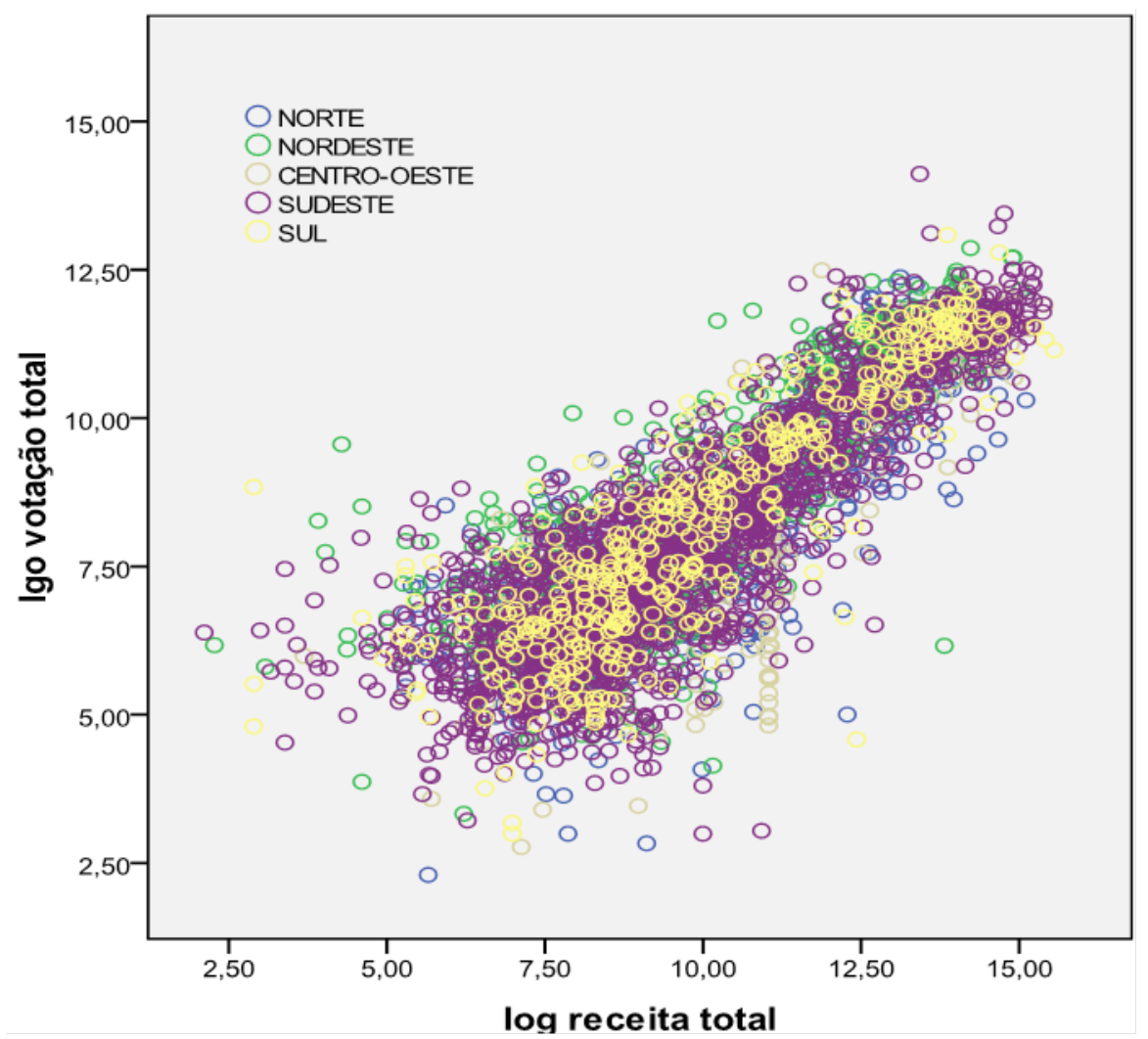

Figure 2 - Relationship between funds raised (R\$) and individual votes by Brazilian regions for federal deputy in 2010

If the distribution of cases allows us to identify the differences between macro-regions, Figure 3 shows the coefficients of determination by electoral district, which is indeed the point in question. Here the differences are shown concerning the strength of the relationship between the two variables by electoral district, varying from an $r^{2}$ of over 0.800 for the state of Paraíba and an $r^{2}$ of just over 0.400 in Acre. In addition to revealing the magnitude of the differences in the relationships between campaign resources and number of votes, the graph also shows the low utility of analyzing the relationships between variables by the aggregate of the mesoregions, since electoral districts in the same region assume different positions in the graph. For example, the three largest coefficients, Paraíba, Minas Gerais and Ceará, belong to different regions: the north, south-east and north-east, respectively. These initial "findings" enable us to conclude that drawing direct comparisons between the effect of financing and votes among candidates of different Brazilian states is not recommended, even when the election is for the same post and follows the same rules.
Analyses of election campaign donations and donors have proved to be highly productive when the aim is to understand the hitherto overlooked contextual aspects of elections (La Raja, 2014; Hooge et al, 2006; Mann, 1999; Scarrow, 2004; Fisher, 2004). Furthermore, the empirical treatment of election results, with mathematical analysis and the creation of indices, is increasingly being used as a research tool. According to Peña,

the data on voting and seats allocated to each party have enabled us to add simple indicators that are intended to explain the distributions and differences observed in a single datum (2005, p. 235, translated from the original Spanish).

The issue is to identify how far simple indicators that overlook the particular aspects of electoral systems can be reproduced when seeking to generalize the results. To what extent are gains in comparability greater than the representation of the particular aspects of each election? Is it possible to find campaign effects that are effectually comparable 


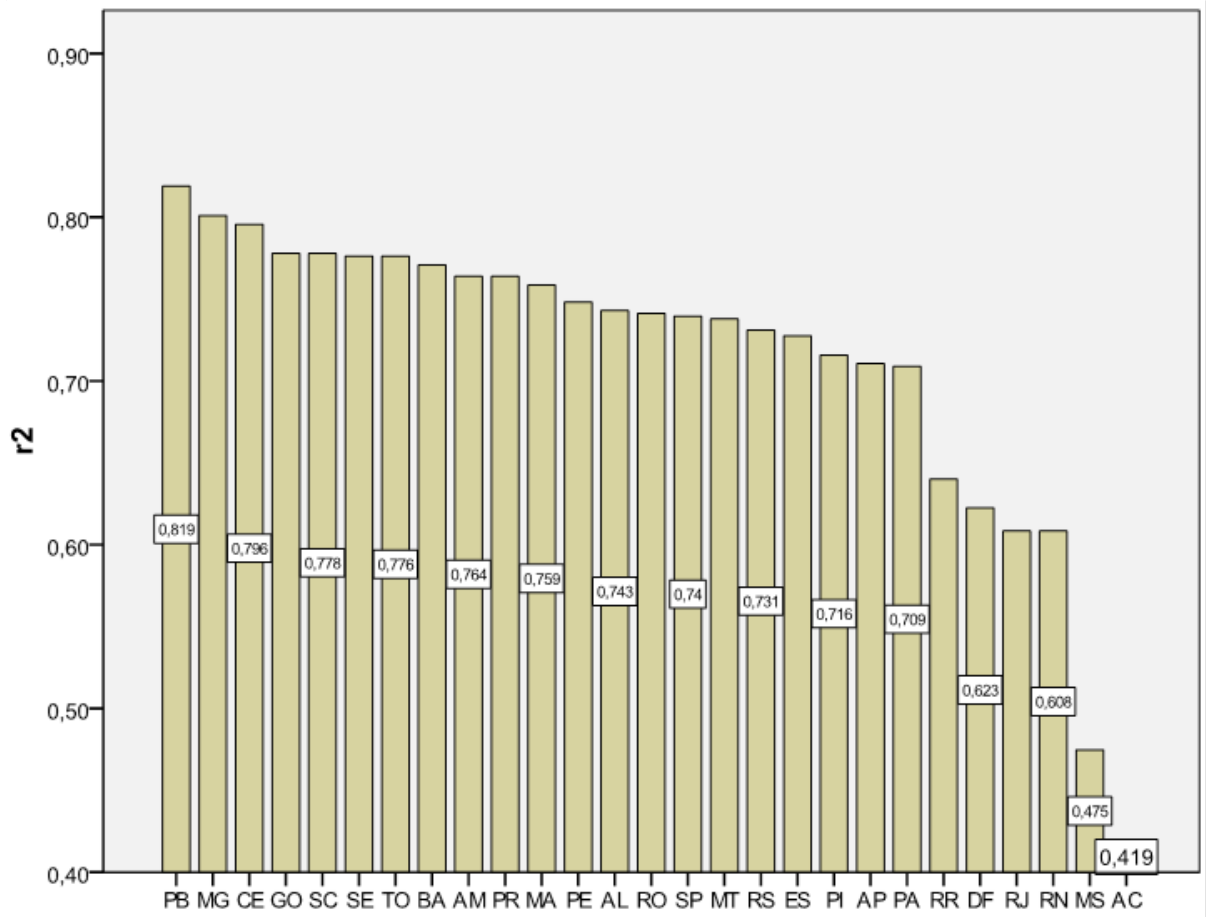

Figure 3- Representation of $\mathrm{r}^{2}$ by electoral district for the relationship between campaign resources and votes for federal deputy in 2010.

in electoral districts with contextual differences? Brazilian national elections, which are held in 27 electoral districts simultaneously, are a suitable object of analysis for seeking the answers to these questions.

The aim of this paper is to test the impact of financial resources on votes relative to two variables: the level of competition for each seat and the economic wealth of each electoral district. The former is related to the ability of the political elite to field candidates to run for office ${ }^{3}$. As the effective number of candidates varies from one district to another, we consider any comparison of the effects of campaign resources that overlooks the differences in the number of effective candidates as being inadequate to the task. As the maximum number of candidates permitted by law is proportional to the number of voters, in districts with a lower effective number, there are potentially more resources available for candidates to finance their campaigns. The second variable has to do with the economic development of each electoral district, as measured by GDP per capita. As the object of analysis here is the 2010 election for federal deputy, the electoral districts are the Brazilian states.
The hypothesis tested here is that the impact on votes of the resources raised by candidates is linked to the competitiveness and economic development of the electoral districts. In more economically developed states (as measured by GDP per capita) and states with a higher number of candidates, financial resources would have less of an effect on votes. However, in states with a lower per capita income and fewer candidates, the correlation between votes and financial resources would tend to increase. The idea is that in poorer states with fewer candidates, the effects of the monetization of campaigns would be different from what would occur in richer states with a higher number of candidates for a federal deputy's seat.

For this purpose, we propose an index that controls the effects of monetization on campaigns. Here, the term "monetized campaigns" is used as a measurement for identifying the effects of monetary resources on electoral performance. The proposal includes the construction of an index that groups the twenty-seven Brazilian electoral districts into four categories: i) The least monetized (MeM), in electoral districts with low GDP per capita and fewer effective candidates; ii) Limited Monetization due to Economic Scarcity (MLiE), for districts with low GDP per capita but a higher ratio of effective 
candidates; iii) Limited Monetization due to political scarcity, where the GDP per capita is high but the proportion of candidates is low; and iv) The Most Monetized (MaM), for districts with high GDP per capita and a high proportion of candidates.

Two sources provide information for the tests, both available on the website of the Supreme Electoral Court (Tribunal Superior Eleitoral - TSE). The first is the performance of candidates for federal deputy in 2010; the other is candidate accountability. As the information from the two databases needs to be cross-referenced, only candidates who received votes and accounted for their campaign donations and expenditure during the campaign were taken into consideration. As a result, a total of 4,124 cases were included in the study. Information was also obtained from the Brazilian Institute of Geography and Statistics (IBGE) concerning the composition of GDP per capita for each state in 2008.

The remainder of this paper is divided into three parts. The first includes the variables and the model for creating the campaign monetization index using two variables: one political (effective proportion of candidates); and one economic (GDP per capita for each state). The index is then tested for candidates for federal deputy for each state in 2010. Finally, some conclusions are given regarding the "findings".

\section{Composition of the campaign monetization index}

As stated above, the monetization index is composed of two variables from different dimensions and macro-coverage. One is political, measured in terms of the proportion of candidates in relation to the possible maximum. The other is economic, measured in Brazilian reais to show GDP per capita per electoral district for election to federal deputy. With this information in hand, we intend to establish a regional and non-individual pattern that enables a comparison of the effects of resources between districts with different characteristics. The composition of the values of these two variables results in what is referred to here as the monetization index, composed of four categories to monitor the effects of resources per number of candidates and the wealth of the electoral district. There now follow the stages for calculating this index.

\section{1 - Weighting by the proportion of effective candidates}

First of all, it is necessary to find the weighted number of effective candidates per electoral district. This is because the more candidates there are, the more "expensive" the available money for campaign finance becomes. The limited number of candidates per district is defined by the number of seats that each district is entitled to in the Chamber of Deputies. Therefore, the closer the number of candidates is to the maximum number permitted, the greater the demand for resources in that district to finance campaigns ${ }^{4}$.

Law 9504/97 establishes the maximum number of candidates in each district. For federal deputy, the following criteria are used: in districts with up to twenty seats in the Chamber of Deputies, parties that are not part of a coalition can field up to twice the number of seats, while coalitions, irrespective of the number of parties involved, can field up to 2.5 times the number of seats. For example, in a district with a minimum number of eight seats in congress, each non-coalition party can field up to sixteen candidates, while each coalition can field up to twenty. In electoral districts with over twenty seats, a party that is not part of a coalition can field up to 1.5 times the number of seats and each coalition can field up to twice the number of candidates. Therefore, in a district with thirty seats in the Chamber of Deputies, a "lone" party can field up to forty-five candidates, while each coalition can field up to sixty. According to these rules, the number of candidates for federal deputy in Brazil per electoral district varies in accordance with three main factors:

- Number of parties fielding candidates: the more parties, the higher the number of candidates;

- Number of coalitions: although coalitions may field $50 \%$ more candidates, when there is a large number of parties in a coalition, there is an opposite 
effect, reducing the number of candidates in each party that makes up the coalition;

- Effective number of candidates per party and/ or coalition: current legislation sets a maximum number of candidates but not a minimum. Therefore, in theory, parties can field as many candidates as they want up to the legal limit.

The calculation to arrive at the effective proportion of candidates is simple:

$$
E P C=\frac{R N C}{P N C}
$$

Where:

$E P C=$ Effective Proportion of Candidates in the electoral district;

RNC $=$ Real Number of Candidates;

PNC $=$ Possible Number of Candidates.

If in an electoral district the effective number of candidates were the same as the maximum, the proportion would be 1 (one), i.e., $100 \%$ of the candidatures for candidates for federal deputy would be taken. For the federal elections of 2010, the TSE registered 102 party coalitions in the twenty-seven electoral districts, totaling 128 lists with different compositions. In accordance with the legislation and the number of parties and coalitions running for office in 2010, if they had all fielded the maximum number, there would have been 9,243 candidates. However, the number of candidates that actually ran for office was 4,124 , which means a total proportion of 0.44 . In other words, the political parties fielded less than half the total number of candidates that they were entitled to field in 2010. This proportion of 0.44 is the nationwide median. However, there were differences in the proportions of effective candidates for each electoral district ${ }^{5}$. Table 1 shows the number of effective candidates for each electoral district, the maximum number of candidates and the proportion. The table shows the proportion of candidates in descending order.

Tocantins had the highest proportion of candidates (0.93), with 37 out of a maximum of 40 . The district with the lowest proportion of candidates was Ceará. With 22 seats in the Chamber of Deputies, considering the number of parties and coalitions in the 2010 election, Ceará could have fielded up to 357 candidates, but only 82 were actually registered, an effective proportion of 0.23 . If all the electoral districts had the same level of economic development, in Tocantins there would potentially be fewer resources available for each individual candidate than in Ceará, where the proportion of candidates was approximately five times lower.

The proportion of effective candidates is the first component of the monetization index. However, on its own it is not enough to equate candidates by financial resources, unless all the districts had the same level of economic development and as a result had the same amounts of resources for election campaigns. As this is not the case in Brazil, where there are high levels of macroeconomic inequality from one region to another, it is also necessary to weight the availability of resources for election campaigns in terms of GDP per capita.

\subsection{Weighting GDP per capita in electoral districts}

The aim here is to place more emphasis on the less economically developed districts. This is because in richer districts there is greater monetization of election campaigns in absolute terms.

To arrive at the proportion of wealth in electoral districts, the district with the lowest GDP per capita is used as a parameter (value 1). All the other districts will be inversely proportionate to it. In 2008, according to the IBGE, Piauí had the lowest GDP per capita in Brazil, at $R \$ 5,372.56$. The formula for the proportion is:

$$
P G d p=\frac{G D P_{-} P I}{G D P_{-} e d}
$$

Where:

PGdp $=$ Proportion of GDP per capita in relation to Piauí;

GDP_PI = GDP per capita for Piauí in 2008;

GDP_ed = GDP per capita of the electoral district in 2008.

As GDP per capita in Maranhão is only $12 \%$ higher than that of Piauí, the weighting for this district is 0.88. However, in the case of the Distrito Federal, the highest GDP per capita in Brazil in 2008, the difference is almost ten times higher and the proportion is only 0.12 . This means that in the 
Table 1 - Proportion of effective candidates in relation to the maximum permitted per legal district - Chamber of Deputies, 2010

\begin{tabular}{|c|c|c|c|c|}
\hline STATE & SEATS & MAX \# CAND* & $\begin{array}{l}\text { EFFECTIVE \# } \\
\text { CAND }\end{array}$ & PROPORTION \\
\hline TO & 8 & 40 & 37 & 0.93 \\
\hline MS & 8 & 76 & 66 & 0.87 \\
\hline RO & 8 & 76 & 65 & 0.86 \\
\hline$A C$ & 8 & 40 & 34 & 0.85 \\
\hline ES & 10 & 119 & 68 & 0.57 \\
\hline $\mathrm{SP}$ & 70 & 1845 & 978 & 0.53 \\
\hline MT & 8 & 112 & 58 & 0.52 \\
\hline RJ & 46 & 1156 & 601 & 0.52 \\
\hline $\mathrm{RR}$ & 8 & 92 & 48 & 0.52 \\
\hline AP & 8 & 112 & 57 & 0.51 \\
\hline SC & 16 & 278 & 136 & 0.49 \\
\hline $\mathrm{DF}$ & 8 & 158 & 76 & 0.48 \\
\hline $\mathrm{AL}$ & 9 & 107 & 47 & 0.44 \\
\hline GO & 17 & 214 & 94 & 0.44 \\
\hline PR & 30 & 514 & 226 & 0.44 \\
\hline MA & 18 & 290 & 122 & 0.42 \\
\hline PB & 12 & 162 & 68 & 0.42 \\
\hline MG & 53 & 1124 & 461 & 0.41 \\
\hline $\mathrm{PA}$ & 17 & 230 & 92 & 0.40 \\
\hline SE & 8 & 113 & 44 & 0.39 \\
\hline AM & 8 & 123 & 43 & 0.35 \\
\hline $\mathrm{Pl}$ & 10 & 197 & 67 & 0.34 \\
\hline RS & 31 & 641 & 218 & 0.34 \\
\hline $\mathrm{BA}$ & 39 & 530 & 175 & 0.33 \\
\hline $\mathrm{PE}$ & 25 & 387 & 116 & 0.30 \\
\hline RN & 8 & 150 & 45 & 0.30 \\
\hline $\mathrm{CE}$ & 22 & 357 & 82 & 0.23 \\
\hline TOTAL & 513 & 9243 & 4124 & 0.44 \\
\hline
\end{tabular}

${ }^{*}$ The maximum number of candidates varies because of the number of lone parties and coalitions in the running.

Distrito Federal for each absolute real value of an election campaign, the relative value in Piauí would be almost ten times that of the two districts with proportionally the same effective number of candidates.

By multiplying the weighted value by the total resources raised by the candidates, the result is a sum of resources that can be compared from district to district. Thus, the absolute differences in funds raised by districts with different levels of economic development would be cancelled out by this multiplication.

The value of funds raised by the candidates from a given electoral district can be compared with candidates from other districts with different levels of economic development. If all the districts had 
Table 2 - Value of weighted GDP per capita per electoral district

\begin{tabular}{c|c|c}
\hline STATE & $\begin{array}{c}\text { GDP PER CAPITA } \\
\text { 2008 }\end{array}$ & WEIGHTED VALUE \\
\hline PI & $5,372.56$ & 1.00 \\
\hline MA & $6,103.66$ & 0.88 \\
\hline AL & $6,227.50$ & 0.86 \\
\hline PB & $6,885.98$ & 0.78 \\
\hline CE & $7,111.85$ & 0.76 \\
\hline PA & $7,992.71$ & 0.67 \\
\hline PE & $8,064.95$ & 0.67 \\
\hline RN & $8,202.81$ & 0.66 \\
\hline BA & $8,378.41$ & 0.64 \\
\hline SE & $9,778.96$ & 0.55 \\
\hline AC & $9,896.16$ & 0.54 \\
\hline TO & $10,223.15$ & 0.53 \\
\hline AP & $11,032.67$ & 0.49 \\
\hline RR & $11,844.73$ & 0.45 \\
\hline RO & $11,976.71$ & 0.45 \\
\hline GO & $12,878.52$ & 0.42 \\
\hline AM & $14,014.12$ & 0.38 \\
\hline MS & $14,188.41$ & 0.38 \\
\hline MG & $14,232.81$ & 0.38 \\
\hline PR & $16,927.98$ & 0.32 \\
\hline MT & $17,927.00$ & 0.30 \\
\hline RS & $18,378.17$ & 0.29 \\
\hline ES & $20,230.85$ & 0.27 \\
\hline SC & $20,388.84$ & 0.26 \\
\hline RJ & $21,621.36$ & 0.25 \\
\hline SP & $24,456.88$ & 0.22 \\
\hline DF & $45,977.59$ & 0.12 \\
\hline & & \\
\hline
\end{tabular}

the same proportion of candidates for the election, it would only be necessary to multiply the weighted value in Table 2 by the individual funds raised in order to compare all the candidates. However, as we have seen in Table 1, this would not be adequate. The equation may be represented as:

$$
\text { FPde }=P G D P \times T o t F
$$

Where:

FPde $=$ Funds raised in proportion to the wealth of the electoral district;

PGDP $=$ Proportion of GDP per capita in relation to Piauí;

TotF $=$ Total individual funds as declared to the TSE.

Since not all the electoral districts had the same proportion of candidates, it is also necessary to weight the proportional funds raised by the effective proportion of candidates. This is done by multiplying the value of FRed by the PEC of each district, thus: 
$\mathrm{RWW}=$ FPed $x E P C$

Where:

RWW $=$ Resources weighted by regional wealth and proportion of candidates;

FPed $=$ Funds raised in proportion to the wealth of the electoral district;

$E P C=$ Effective Proportion of Candidates in the electoral district;

Table 3 - Real and weighted values by wealth and number of candidates

\begin{tabular}{c|c|c|c}
\hline STATE & $\begin{array}{c}\text { R\$ } \\
\text { (Median) }\end{array}$ & RWw & $\begin{array}{c}\text { Diff. in } \\
\%\end{array}$ \\
\hline TO & $379,636.13$ & $276,375.10$ & 72.80 \\
\hline AC & $197,913.59$ & $137,846.82$ & 69.65 \\
\hline PI & $163,580.09$ & $109,598.66$ & 67.00 \\
\hline RO & $154,764.37$ & $101,293.28$ & 65.45 \\
\hline AL & $224,916.00$ & $146,532.77$ & 65.15 \\
\hline MA & $127,685.24$ & $82,995.40$ & 65.00 \\
\hline MS & $310,632.17$ & $193,989.79$ & 62.45 \\
\hline PB & $119,436.06$ & $71,661.64$ & 60.00 \\
\hline PA & $157,115.82$ & $84,214.08$ & 53.60 \\
\hline AP & $67,982.78$ & $33,889.41$ & 49.85 \\
\hline CE & $247,926.57$ & $122,103.84$ & 49.25 \\
\hline RR & $280,524.60$ & $136,615.48$ & 48.70 \\
\hline BA & $240,648.61$ & $116,834.90$ & 48.55 \\
\hline PE & $313,464.56$ & $151,403.38$ & 48.30 \\
\hline RN & $268,062.01$ & $127,999.61$ & 47.75 \\
\hline SE & $165,959.97$ & $77,918.20$ & 46.95 \\
\hline GO & $586,693.31$ & $251,398.08$ & 42.85 \\
\hline ES & $273,199.05$ & $114,197.20$ & 41.80 \\
\hline MT & $425,094.87$ & $174,288.90$ & 41.00 \\
\hline MG & $266,765.46$ & $104,972.21$ & 39.35 \\
\hline RJ & $145,047.22$ & $55,698.13$ & 38.40 \\
\hline PR & $275,632.81$ & $104,327.02$ & 37.85 \\
\hline SC & $184,647.74$ & $69,612.20$ & 37.70 \\
\hline SP & $222,608.56$ & $83,478.21$ & 37.50 \\
\hline AM & $260,153.98$ & $95,346.43$ & 36.65 \\
\hline RS & $201,680.37$ & $63,731.00$ & 31.60 \\
\hline DF & $183,614.51$ & $54,808.93$ & 29.85 \\
\hline & & &
\end{tabular}


By weighting the proportion of candidates and the proportion of wealth, the individual values of funds raised by the candidates are adjusted. As the indicators are inverted, we hope to obtain a median value between the proportion of candidates and the wealth of the electoral district. The indicator is inverted because in relation to GDP per capita the greatest weights lie in the poorest electoral districts, whereas when it comes to the indicator for effective candidates, the greatest weight lies in the districts with the highest proportion of candidates. The result of this is that there is compensation between availability of resources and candidates in each district. From a theoretical viewpoint, if the maximum number of candidates were fielded in the richest district, it would lie at the heart of the distribution: in 14th place in the ranking of states.

Table 3, above, shows the percentage differences between the median values of funds raised by candidates according to electoral district and the weighted values for GDP per capita and the effective number of candidates. According to the table, Tocantins showed the least difference between the original median of funds raised per federal deputy, the weighted value for GDP per capita and the effective number of candidates. The median weighted funds accounted for $72.8 \%$ of the original median. The greatest median difference was that of the Distrito Federal, where the weighted value represented only $29.85 \%$ of the median declared funds raised for the election campaigns.

The final step for verifying the effectiveness of the monetization index is to determine whether the weightings had no significant effect on the relationship between campaign finance and votes. If the coefficient of determination varies a great deal in relation to the original, this means that the index is artificially biased. If the all-in result of the coefficient of determination of the weighted values is close to the original, the explanatory model remains adjusted, even after weighting. Using the variables transformed into logarithms of the nominal voting and the weighting of values by GDP and effective candidates (RWW), the $r^{2}$ of 0.698 is therefore practically the same as shown in Figure 1 ( $r^{2}$ of 0.700 ). With this result, we can now move on and propose a typology for the types of election for federal deputy with the controlled monetization of campaigns, which will be seen in the next section.

\section{A typology for comparing electoral districts in Brazil}

Considering the two variables for weighting the effects of campaign finance, we propose a categorization. First of all, we will divide them into two groups, using the median of the proportion of effective candidates: below the median, 0.490, electoral districts with low numbers of candidates and, above the median, districts with a higher proportion of candidates. Following the same logic for the economic variable, we will divide them into two equal groups, using the median of 0.450 of the proportion of GDP per capita, with the more economically developed districts (below the median) and the less developed ones (above the median) ${ }^{6}$. By combining the groups of binary variables, we create a new categorization that considers both the political and economic dimensions jointly, as shown in Chart 1, below. The distribution of electoral districts in 2010 regarding campaign financing with controlled monetization may be shown as it follows.

With the categories defined, from here on tests will be conducted to gauge the performance of the candidates in each type of electoral district and degree of campaign finance. We begin by testing the differences between the money raised by candidates and the number of votes gained by type of election. When gauging the difference in the proportion of finance per vote among those who were and were not elected, we can see a concentration of resources on more electorally viable candidates for each type of district. The greater the difference, the more financing is concentrated on candidates who are most likely to win. The lower the difference, the more equality there is in the distribution of campaign finance.

When analyzing the different medians of reais per vote among the elected and unelected (Table 4), we see that votes are cheaper for the elected candidates in all categories. However, in districts with less monetization (MeM), the distance between them is greater. Those who were not elected had on average $82.33 \%$ more reais per vote than those who were elected, with $R \$ 6.56$ over $\mathrm{R} \$ 3.60$. The second largest difference is in more monetized districts (MaM), with an average of $39.92 \%$ more reais per vote for the unelected over the elected. Then come the districts with 
Chart 1 - Distribution of Electoral districts by form of monetization in 2010

\begin{tabular}{|c|c|c|c|}
\hline & \multicolumn{3}{|c|}{ GDP per capita } \\
\hline & - & + & \\
\hline \multirow{2}{*}{$\begin{array}{c}\text { Proportion } \\
\text { of } \\
\text { candidates }\end{array}$} & $\begin{array}{c}-+ \\
(\mathrm{MLiE})\end{array}$ & \multicolumn{2}{|l|}{$\begin{array}{c}++ \\
(\mathrm{MaM})\end{array}$} \\
\hline & $\begin{array}{c}-\cdot \\
(\mathrm{MeM})\end{array}$ & $\begin{array}{c}+- \\
(\mathrm{MLiP})\end{array}$ & \\
\hline CATEGORY & DEFINITION & EDs & N (\% Total) \\
\hline $\begin{array}{l}\text { Least monetized } \\
\text { (MeM). }\end{array}$ & $\begin{array}{l}\text { Electoral districts with low GDP per } \\
\text { capita and low proportion of } \\
\text { candidates. }\end{array}$ & $\begin{array}{l}\text { BA,CE, MA, } \\
\text { PA, PB, PE, PI, } \\
\text { RN, SE. }\end{array}$ & $9(33.33 \%)$ \\
\hline $\begin{array}{l}\text { Limited monetization } \\
\text { due to economic } \\
\text { scarcity (MLiE). }\end{array}$ & $\begin{array}{l}\text { Electoral districts with low GDP per } \\
\text { capita and high proportion of } \\
\text { candidates. }\end{array}$ & $\begin{array}{l}\text { AC, AL, AM, } \\
\text { RO, RR, TO. }\end{array}$ & $6(22.22 \%)$ \\
\hline $\begin{array}{l}\text { Limited monetization } \\
\text { due to political scarcity } \\
\text { (MLiP). }\end{array}$ & $\begin{array}{l}\text { Electoral districts with high GDP per } \\
\text { capita and low proportion of } \\
\text { candidates. }\end{array}$ & AM, MG, RS. & $3(11.11 \%)$ \\
\hline $\begin{array}{l}\text { Most monetized } \\
\text { (MaM). }\end{array}$ & $\begin{array}{l}\text { Electoral districts with high GDP per } \\
\text { capita and high proportion of } \\
\text { candidates. }\end{array}$ & $\begin{array}{l}\text { DF, ES, GO, } \\
\text { MS, MT, PR, } \\
\text { RJ, SC, SP. }\end{array}$ & $9(33.33 \%)$ \\
\hline
\end{tabular}

limited monetization due to political scarcity, with a difference of $29.94 \%$. Finally, there are the districts with monetization limited by economic scarcity, with a difference of $14.61 \%$. These results show that where there are fewer resources available and fewer candidates, donations tend to be concentrated on the campaigns of candidates who are more likely to be elected. Proportionally, the average difference of the less monetized ones is twice as high as the difference of the more monetized, coming in second place in terms of concentration of resources on candidates who are more likely to be elected.

The ANOVA test of the differences in means between elected and unelected candidates by categories of monetization shows that the mean differences among the unelected are statistically significant. Therefore they are strong for the relationship among almost all the categories, except less monetized disputes (MeM) and those of monetization limited by political scarcity (MLiP). This means that among the total number of candidates, the differences are significant for almost all the categories. Nevertheless, when looking at the median differences of the elected candidates, we see that the only statistically significant strong differences are among candidates from less monetized districts (MeM) in relation to the others. The other three categories of elected candidates showed no significant median differences (highlighted in red in Table 4). This means that whereas for the unelected the level of monetization of the electoral district matters when it comes to the $\mathrm{R} \$$ /vote ratio, but for the elected candidates, it does not.

These results show that in situations of economic and political scarcity (low GDP and high effective proportion of candidates) there is a drop in the financial values necessary for candidates to win votes. Less money and fewer candidates mean that the campaign finance of elected candidates is similar to that of the unelected. However, the lowest general difference, unlike what one would imagine, is not between MeM and MLiE but is actually the difference between MeM and MLiP. This means that in districts with limited candidates, the volumes of resources are lower than in districts with economic limitations, i.e., the campaigns are more egalitarian in terms of finance when there are fewer candidates 
Table 4 - Medians between $\mathrm{R} \$$ per vote obtained by the categories of monetization

\begin{tabular}{l|r|c|r|r|c|c}
\hline \multirow{2}{*}{ Categories } & \multicolumn{2}{|c|}{ Total } & \multicolumn{2}{c|}{ Elected } & \multicolumn{2}{c}{ Differences } \\
\cline { 2 - 7 } & $\begin{array}{c}\text { Media } \\
\mathbf{n n y y y y y}\end{array}$ & D.P. & $\begin{array}{c}\text { Media } \\
\mathbf{n}\end{array}$ & D.P. & Median & D.P. \\
\hline MeM & 6.564 & 56.113 & 3.60 & 2.460 & $-2.94(82.33 \%)$ & -53.653 \\
\hline MLiE & 17.893 & 68.648 & 13.77 & 16.455 & $-4.12(29.94 \%)$ & -52.193 \\
\hline MLiP & 4.871 & 33.565 & 4.25 & 2.940 & $-0.62(14.61 \%)$ & -30.625 \\
\hline MaM & 7.010 & 29.548 & 5.01 & 4.028 & $-2.00(39.92 \%)$ & -25.520 \\
\hline
\end{tabular}

\begin{tabular}{l|l|r|r|r|r}
\hline \multirow{4}{*}{ (I) Category } & \multirow{2}{*}{$\begin{array}{c}\text { (J) } \\
\text { Category }\end{array}$} & $\begin{array}{c}\text { Median Diff. (I- } \\
\text { J) }\end{array}$ & \multicolumn{2}{c|}{ Sig. } & \multicolumn{2}{c}{ Elected } \\
\cline { 2 - 6 } MeM & MLiE & -3.831 & 0.000 & -5.180 & 0.000 \\
\cline { 2 - 6 } & MLiP & -0.638 & 0.538 & -4.154 & 0.000 \\
\cline { 2 - 6 } & MaM & -1.965 & 0.000 & -4.045 & 0.000 \\
\hline \multirow{4}{*}{ MLiE } & MeM & 3.831 & 0.000 & 5.180 & 0.000 \\
\cline { 2 - 6 } & MLiP & 3.193 & 0.000 & 1.026 & 1.000 \\
\cline { 2 - 6 } & MaM & 1.866 & 0.001 & 1.135 & 1.000 \\
\hline \multirow{4}{*}{ MLiP } & MeM & 0.638 & 0.538 & 4.154 & 0.000 \\
\cline { 2 - 6 } & MLiE & -3.193 & 0.000 & -1.026 & 1.000 \\
\cline { 2 - 6 } & MaM & -1.327 & 0.000 & 0.109 & 1.000 \\
\hline \multirow{3}{*}{ MaM } & MeM & 1.965 & 0.000 & 4.045 & 0.000 \\
\cline { 2 - 6 } & MLiE & -1.866 & 0.001 & -1.135 & 1.000 \\
\cline { 2 - 6 } & MLiP & 1.327 & 0.000 & -0.109 & 1.000 \\
\hline \hline
\end{tabular}

than in an electoral district with less wealth. In other words, although there is economic wealth in the district, campaign donations are limited by the low number of candidates. This limitation is greater than that found in districts were levels of wealth are low but the proportion of candidates is high (MLiP).

Having conducted analyses on the impact of financial resources on votes, we now move on to test the index with three individual variables: i) origin of the candidate and whether he/she is a professional politician; ii) the gender of the candidate; and iii) the candidate's type of party coalition. In all cases, the results are divided by all the candidates and then only by the elected candidates to see whether there are behavioral differences between all the candidates and the elected candidates ${ }^{7}$.

Table 5 shows the relationship between categories of monetization and whether the candidate is a professional politician for all candidates and then only those who were elected. When we consider the whole set of candidates, there are no significant differences in terms of whether the politician is a professional in any of the categories. All the residuals lay between \pm 1.96 and the $q^{2}$ is 4.031 .

When only elected candidates are considered, there is a concentration of significant negative residuals (-2.4) for non-professional politicians in elections with limited monetization and political scarcity. There are also significant positive residuals (2.1) in the same category. This raises the $q^{2}$ to 13.459 , making it statistically significant. The interpretation of this distribution is that there are more likely to be professional politicians in districts with a low effective number of candidates, i.e., districts with 
Table 5 - Distribution of Professional Politicians by type of monetization

\begin{tabular}{l|r|r|r|r}
\hline \multirow{2}{*}{$\begin{array}{l}\text { Category of } \\
\text { candidates }\end{array}$} & \multicolumn{3}{|c|}{ Professional politician } \\
\cline { 2 - 5 } & \multicolumn{2}{|c|}{ All } & \multicolumn{2}{c}{ Elected } \\
\cline { 2 - 5 } MeM & No & Yes & No & \multicolumn{1}{c}{ Yes } \\
\hline MliE & -0.4 & 1.3 & 0.4 & -0.4 \\
\hline MliP & 0.1 & -0.3 & 1.1 & -1.0 \\
\hline MaM & -0.2 & 0.8 & -2.4 & 2.1 \\
\hline q-squared & 0.3 & -1.1 & 0.7 & -0.6 \\
\hline & $4.031(0.258)$ & 13.459 & $(0.004)$ \\
\hline
\end{tabular}

a lower proportion of candidates tended to elect more professional politicians to the Chamber of Deputies in 2010.

The second variable tested here is gender, in order to identify whether women tend to be concentrated in a certain monetization category. Unlike the previous variable, Table 6 shows that the $\mathrm{q}^{2}$ coefficients are significant for all candidates and those who were elected, with coefficients of 20.308 and 12.080 , respectively. This means that at least one of the residuals of each group was over the critical limit. We can see that the significant residuals (in red in Table 6) are for women, both among all candidates and those who were elected. This means that in the case of men, the candidate distribution, irrespective of whether they are elected, is not concentrated in any of the categories of monetization.

In the case of women, among all the candidates there is a significant negative trend (-3.1) in less monetized campaigns and a significant positive trend in more monetized campaigns (2.0). This means that in more economically developed districts with a higher proportion of candidates, more women tend to be involved. The presence of women in districts with a higher proportion of candidates was to be expected because, owing to the gender quotas, the more women there are, the higher the proportion of candidates there can be. However, in less economically developed districts there are fewer women than expected among the candidates. This means that economic development played a positive role in the involvement of women in the 2010 campaign for federal deputy.

Nevertheless, the fact that there are more female candidates in economically developed districts does not mean that they will be more successful and win elections. On the contrary, the standardized residuals for the elected candidates show that the only category with a significant residual for women was that of monetization limited by economic

Table 6 - Distribution of candidate gender by type of monetization

\begin{tabular}{l|r|r|r|r}
\hline \multirow{2}{*}{$\begin{array}{l}\text { Category of } \\
\text { candidature }\end{array}$} & \multicolumn{4}{|c}{ Gender } \\
\cline { 2 - 5 } & \multicolumn{2}{|c|}{ All } & \multicolumn{2}{c}{ Elected } \\
\cline { 2 - 5 } & Women & Men & $\begin{array}{c}\text { Wome } \\
n\end{array}$ & \multicolumn{1}{c}{ Men } \\
\hline MeM & -3.1 & 1.4 & -1.1 & 0.3 \\
\hline MliE & 1.3 & -0.6 & 2.8 & -0.9 \\
\hline MliP & -1.3 & 0.6 & -1.4 & 0.4 \\
\hline MaM & 2.0 & -0.9 & 0.5 & -0.2 \\
\hline q-squared & $20.308(0.000)$ & $12.080(0.007)$ \\
\hline
\end{tabular}


scarcity (MLiE), with a coefficient of 2.8. This means that elected female candidates tended to be concentrated in districts with a high number of effective candidates, but with low economic development. In other words, although in richer districts there is a higher proportion of female candidates, these women tend to do better in districts with low monetization as a result of economic limitations.

The next variable is strictly political. It identifies the relationship between candidates' performance by type of coalition. It is based on the assumption that parties that form a coalition with the party that won the presidential election, the PT, have specific characteristics by type of monetization. If the hypothesis of dependence on the State and a link between votes and economic satisfaction is correct, poorer districts will tend to elect more candidates from the PT or parties that form a coalition with it. For this purpose, the candidates were placed in three groups: i) in coalitions without the PT for parties that decided to form coalitions, irrespective of being opponents of the PT; ii) a coalition with the PT for candidates from parties that joined forces with the PT or PT candidates that joined forces with other parties; and iii) the PT with no coalition, for candidates in districts where the PT opted not to join forces with any other party.

Table 7 shows that the coefficients of the $q^{2}$ test were higher than those of the previous variables. The $\mathrm{q}^{2}$ for all the candidates was $139.347(0.000)$, and for the elected candidates it was 79.765 (0.000). This shows that at least one of the relationships between the categories of all the candidates and those who were elected was over the critical limit.
If we consider the results for the set of candidates, the districts with lower monetization tended to field less candidates in coalitions without the PT $(-2.6)$ and fewer candidates from the PT without a coalition $(-2.5)$. In these same districts, we tend to see more candidates in coalitions with the PT (7.9). In districts with limited monetization due to economic scarcity, the only significant and positive residual is that of candidates in coalitions with the PT (4.1). In the more monetized districts, the positive residuals are for candidates in coalitions without the participation of the PT (2.0) and the negative residuals are for candidates in coalitions with the PT (-6.0). These results allow us to affirm that in poorer districts with a lower proportion of effective candidates there is a tendency to concentrate candidates in coalitions with the ruling party. In more developed districts with a higher proportion of candidates, there is a tendency for candidates to join parties that are not in a partnership with the PT.

In the case of elected candidates, the residuals are closer to those found for the whole set of candidates. As shown in Table 7, above, in less monetized districts there is a lower proportion of candidates in non-PT coalitions (-3.5) and candidates from the PT without a coalition (-2.0). Candidates belonging to parties in coalitions with the PT or who were PT candidates in coalitions were concentrated among the elected candidates in these districts (5.4). The standardized residuals of districts with monetization limited by economic scarcity were low, indicating no relationship. Districts with monetization limited by political scarcity showed significant negative residuals for parties in coalitions with the PT (-2.1) and positive

Table 7 - Distribution of type of party coalition by type of monetization

\begin{tabular}{l|r|r|r|r|r|r}
\hline \multirow{2}{*}{ Categories } & \multicolumn{4}{|c|}{ All } & \multicolumn{3}{c}{ Elected } \\
\cline { 2 - 8 } & $\begin{array}{c}\text { Coalition } \\
\text { without PT }\end{array}$ & $\begin{array}{c}\text { Coalition with } \\
\text { PT }\end{array}$ & $\begin{array}{c}\text { PT without } \\
\text { coalition }\end{array}$ & $\begin{array}{c}\text { Coalition } \\
\text { without PT }\end{array}$ & $\begin{array}{c}\text { Coalition with } \\
\text { PT }\end{array}$ & $\begin{array}{c}\text { PT without } \\
\text { coalition }\end{array}$ \\
\hline MeM & -2.6 & 7.9 & -2.5 & -3.5 & 5.4 & -2.0 \\
\hline MliE & -1.3 & 4.1 & -1.5 & 0.5 & -0.3 & -1.1 \\
\hline MliP & -0.2 & 0.3 & 1.3 & 0.8 & -2.1 & 3.7 \\
\hline MaM & 2.0 & -6.0 & 1.2 & 2.3 & -3.1 & -0.2 \\
\hline q-squared & \multicolumn{4}{|c|}{$139.347(0.000)$} & \multicolumn{3}{c}{$79.765(0.000)$} \\
\hline
\end{tabular}


for PT candidates without a coalition (3.7). In more monetized districts, the positive significant residuals were for candidates in non-PT coalitions (2.3) and the negative residuals were for parties in coalitions with the PT (-3.1).

We can tentatively state that elections in less economically developed districts with a low proportion of candidates tend to benefit the governing party and its political allies (parties in coalitions with the PT). In these districts candidates who are not in a coalition with the PT are less likely to be elected. On the other hand, in more economically developed districts with a higher proportion of candidates, parties that are not working with the PT tend to fare better and candidates linked to the governing party tend not to be elected.

\section{Concluding Notes}

As Brazil is such a large country, no matter how much its electoral laws attempt to establish a single formula for all electoral districts, regional aspects and other local factors must be taken into account when making a comparative analysis of the political indicators. This is even more important when the analysis has to do with campaign finance and how financial resources are turned into votes. Analyses using nationwide data regarding campaign financing that do not take regional differences into account run a high risk of reaching distorted and reckless conclusions. If we consider only the object of study here, the 2010 federal deputy elections, and look at two variables in this context, i.e., the economic and the political aspects, we see significant differences.

From an economic viewpoint, the district with the highest GDP per capita, the Distrito Federal, enjoyed a GDP per capita in 2008 that was almost ten times higher than that of the district with the lowest index, Piauí. This difference alone is an indication of the scarcity of resources for campaigns in Piauí in comparison with the Distrito Federal, and this means that it is necessary to weight the "value of money" in election campaigns under such different economic conditions. In addition to the availability of money on the "market", we also have to consider the candidates competing for these resources. The higher the proportion of candidates, the more hotly disputed these resources will be. In 2010 , on average, $44 \%$ of the possible candidacies were filled, in accordance with the electoral laws of the day. If all the districts had the same proportion of candidates this would not be a problem. The point in question is that the proportion of effective candidates varies greatly. In the elections for the Chamber of Deputies in 2010, the electoral district with the highest proportion of candidates in relation to the maximum number permitted was Tocantins, with 0.93 , and the lowest proportion was Ceará, with 0.23 .

Because of the regional inequalities in both political and economic terms, an effort has been made here to categorize the elections according to the degree of monetization of each district, taking into account the GDP per capita and effective proportion of candidates. In this way it was possible to categorize Less Monetized districts (MeM), where there is little wealth and a lower proportion of effective candidates. It was also possible to categorize the More Monetized districts (MaM), with high levels of wealth and a higher proportion of effective candidates. Between these two poles, there are other categories: Monetization Limited by Economic Scarcity (MLiE), for districts with low economic wealth but a high proportion of effective candidates; and Monetization Limited by Political Scarcity (MLiP), with high levels of economic wealth but a low proportion of effective candidates.

Tests concerning the impact of financial resources on campaigns proved that they were very similar for the crude model but had economic and political differences when weighted. The regression between the total votes and campaign funds raised showed an $r^{2}$ of 0.394 without weighting and an $r^{2}$ of 0.386 after being weighted by the two variables, indicating very similar adjustments in both cases. However, the Beta $(\beta)$ coefficient of the weighted model was slightly higher than that of the model prior to weighting, with $\beta=0.132$ and $\beta=0.056$, respectively.

With the indicator showing that the impact of individual campaign finance is sensitive to 
weighting by regional wealth and proportion of candidates, we conducted tests to identify possible electoral performance patterns of candidates according to other variables. The first had to do with the difference in the reais/votes ratio for elected and unelected candidates in the four campaign monetization categories. This test found (Table 4) that elected candidates won more votes for each real raised in all districts. Nevertheless, the difference is greater in Less Monetized districts, with an average difference in excess of $80 \%$. In other words, to receive a vote, a defeated candidate in a Less Monetized district requires 1.8 times more resources than an elected candidate. The proportional difference in More Monetized (MaM) districts was just over $40 \%$. Districts with Monetization Limited by Political Scarcity (MLiP) had the lowest differences between elected and defeated candidates in terms of converting financial resources into votes. In other words, the more candidates running for office, the more equal the financial conditions between the elected and unelected, irrespective of regional wealth.

The second variable measured the performance of candidates who are professional politicians, the other candidates and the type of monetization of their campaigns. When all the candidates are considered, it is impossible to find standardized residuals above the critical limit, which indicates that the distribution is close to what is expected when there is no relationship between the two variables. However, when only elected candidates are considered (see Table 5), in districts with Monetization Limited by Political Scarcity (MLiP) there is a lower proportion of professional politicians among the unelected and a higher proportion among the elected. This means that although in the other types of election being or not being a professional politician makes no difference when it comes to being elected, in conditions of economic wealth and a low proportion of candidates, career politicians tend to fare better.

When considering the relationship between the gender of the candidate and the type of campaign, men are equally spread in all the categories, both in terms of total candidates and those who are elected. Women have some statistically significant residuals. Table 6 shows that when all female candidates are taken into consideration, women tend to dispute elections less in Less Monetized
(MeM) districts and run for office more when the district is More Monetized (MaM). However, this is not reflected in their electoral success. When only elected female candidates are considered, the only strong and positive result is in districts with Monetization Limited by Economic scarcity (MLiE), i.e., women are more successful in districts with low levels of economic development but which have a high proportion of effective candidates. In other words, women ran for office in 2010 in electoral districts with a developed economy, but tended to be elected in less wealthy districts, albeit with a high proportion of candidates.

The final variable to be tested here is political and has to do with how close ties to the governing party, the PT, affect the performance of candidates by type of campaign finance. The candidates were organized into three groups: parties that formed coalitions without the PT, including both single parties and coalitions formed without the governing party, indicating independence from or opposition to the PT; parties in a coalition with the PT, indicating closeness to the governing party; and the PT without any coalitions, for PT candidates that entered the election without joining or forming a coalition with another party. The results (see Table 7) show a relationship between economic/ political development, the fielding of candidates and their rate of success. Parties in coalitions with the PT tend to elect more candidates in districts that are Less Monetized (MeM) and elect fewer candidates in More Monetized (MaM) districts. The opposite occurs with candidates from parties that are not in a coalition with the PT. There is a significant and negative coefficient for elections in MeM districts and a positive one in MaM districts for opposition parties. However, when we consider the relationships for all the candidates, we see that performances are similar. Parties in coalitions with the PT tend to field more candidates in MeM districts and parties not in a coalition with the PT field fewer candidates in these districts. Therefore, the "vote for the government" in poorer districts is directly related to the organization of candidatures by the political elite. As the opposition and independent parties field fewer candidates in districts with low monetization, coalitions with the governing party tend to enjoy higher success rates in these regions.

The results shown here are not intended to be definitive, seeing that it is an analysis of a single 
election campaign for the Chamber of Deputies in 2010. Nevertheless, two main points have been proved: i) the need to regard the impact of financial resources on election campaigns when intending to make comparative analyses or use data at the national level; ii) weighting only using economic variables may be insufficient to explain the differences between Brazilian electoral districts. What proved to be more adequate was joint weighting between economic development (measured by GDP per capita) and the development of political competitiveness (measured by the proportion of effective candidates) to gauge the impact of financial resources on election campaigns. field at least ten candidates of the same gender. Should it manage to field only seven women (or men), there could not be more than twenty-one candidates of the opposite sex. Consequently, the number of effective candidates would fall to twenty-eight, two fewer than the maximum number permitted by law.

${ }^{6}$ Thus, it is inverted, as we opted to leave the least developed electoral districts closer to the maximum value, which is 1 , for Piauí.

7 In order to demonstrate these differences, the standardized residuals that indicate the concentration of cases in the categories will be analyzed. As all the tests have a confidence interval of $95 \%$, the critical limit for the standardized value of an expected distribution is up to \pm 1.96 . Any residual above this limit, either positive or negative, indicates a greater number of cases than would be expected when comparing real distribution with theoretical distribution. The $\mathrm{q}^{2}$ coefficients for all the relationships are also presented, although it is known beforehand that it will only be statistically significant if there is any residual above the critical limit of \pm 1.96 .

\section{BIBLIOGRAPHICAL REFERENCES}

${ }^{1}$ There are at least two major ongoing lines of research into campaign finance in Brazil. One of these will be the object of this study and analyzes the effect of money on votes. The other looks at financing from the viewpoint of the donors and their characteristics, in accordance with the approach taken by researchers such as Speck and Mancuso (2011).

${ }^{2}$ Logarithms in a regression were used owing to the high level of heteroscedasticity perceived in the relationship between the original variables.

3 A preliminary version of this part of the analysis was presented at a round table meeting on Brazilian elections at the 6th Latin-American Congress on Political Science, held in Quito, Ecuador, in June 2012.

${ }^{4}$ For a more in-depth discussion on this point, see: CERVI, Emerson. Comportamiento electoral y nivel de disputa en Brasil. Presented at the Simposio del Grupo de Investigación "Comunicación Política y Comportamiento Electoral". 6th Latin-American Political Science Congress, Alacip, Quito Ecuador, 2012.

${ }^{5}$ It is important to mention that one of the factors that limits the capacity of parties to field $t$ he $m$ aximum $n$ umber of candidates is the rule that establishes a quota of at least 30\% of candidates of the same gender and a maximum of $70 \%$, as determined by Article 10 of law 9504/97. As parties and coalitions cannot usually find enough women to run for $30 \%$ of the vacancies, the solution is to reduce the total number of candidates in order to comply with the rule. Therefore, even though there may be more men willing to run, the parties will limit the number of candidates due to a lack of female candidates. For instance, say that a party can field up to thirty candidates for federal deputy. In this case it would need to
FISHER, Justin; EISENSTADT, Todd. «Introduction: comparative party finance. What is to be done?» Party Politics Review. Vol 10. № 6, 2004. (p. 619-626). adapt: Electoral reform, party finance and party strategy in Belgium» Electoral Studies. № 25, 2006. (p. 351-368)

LA RAJA, Raymond; SCHAFFNER, Brian F. «The effects of campaign finance spending bans on electoral outcomes: Evidence from the states about the potential impact of Citizens United» v. FEC. Electoral Studies. № 33, 2014 (p. 102-114)

MANN, Thomas. «El sistema de financiamiento de campañas em Estados Unidos bajo estúdio: problemas y perspectivas de cambio» Revista Ciencia Politica. Chile. Vol. 20. № 1, 1999 (p. 61 a 84).

PEÑA, Ricardo. «El número de Autonomías y la competitividad electoral» Política y Cultura. Otoño, 2005. N. 24 p. 233 a 255.

SCARROW, Susan E. Explaining political finance reforms: competition and context. Party Politics Review. Vol 10. № 6, 2004. (p. 653 a 675).

SPECK, Bruno W. \& MANCUSO, Wagner P. «O financiamento político nas eleições brasileiras de 2010: um panorama geral» Paper apresentado no $35^{\circ}$ Encontro Anual da Anpocs, Caxambu-MG, 2011.

TAAGEPERA, Rein \& SHUGART, M.S. Seats \& Votes: The effects \& determinats of Electoral Systems. New Haven: Yale University Press, 1989.
HOOGE, Marc; MADDENS, Bart; NOPPE, Jo. «Why parties 